\title{
COVID-19 Pandemic and Antecedents for Digital Transformation in the Workplace: A Conceptual Framework
}

\author{
Maxwell Olokundun*, Stephen Ibidunni, Mercy Ogbari, Hezekiah Falola, Odunayo Salau \\ Department of Business Management, Covenant University, Ota, Ogun State, Nigeria
}

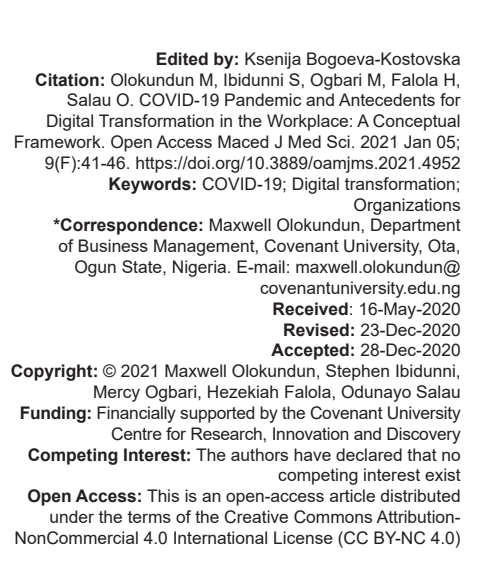

\begin{abstract}
The emergence of coronavirus (COVID-19) has caused us to reconsider our everyday lives around the world While the ability to work from home is an advantage to many workers, other businesses lack the foundation of the technological infrastructure to give the capacity of "business as usual" without some compromises. The goal of this paper is to develop a conceptual framework on digital transformations antecedents of global workplaces and organizations post-pandemic outbreak. The study emphasized that the most effective transformations point to four antecedents; smart capital allocation for digital initiatives, engagement of appropriate digital tools, talent recruitment, and brand permission. The study concluded that the global pandemic has created a whole new experience for businesses and organizations around the world. Therefore, business executives cannot sit on their laurels any longer and they cannot put off a digital transformation organizational focus. Henceforth, taking the right decisions today would help ensure that businesses are better placed after the pandemic is over.
\end{abstract}

\section{Introduction}

COVID-19's rapid spread poses an unprecedented health problem the planet is dealing with. While the effects on human cannot be overemphasized, there are also major economic, business, and industry impacts that are felt globally. The impacts will continue to propagate, as viruses know no boundaries. Nonetheless, a greater percent of the companies in Africa have been affected and are already experiencing COVID-19 disruptions. Businesses in Asia and parts of Europe were negatively affected. Shopping malls and restaurants are abandoned when revenues from travel and tourism crash. It is therefore critical for companies to be vigilant in assessing their capacity to withstand disruption from both an operational and a financial perspective, and to act decisively to mitigate real or potential problems. The emergence of coronavirus (COVID-19) has caused us to reconsider our everyday lives around the world. Several people switched to digital platforms to preserve a certain sense of normality in response to travel restrictions, school suspensions, warnings not to meet in big crowds and keep our distance from fellow human beings to restrict the spread of the virus. Digitally changing our workplaces to be able to run efficiently has become crucial [1]. Firms willing to use technologies successfully to continue reinventing their business strategies for the future by tracking new developments rapidly would be ahead of their competition [2]. Furthermore, businesses that were immune to the idea of a mobile workplace were forced to encourage work from home while taking steps to avoid the spread of the virus. Much of the time, only major corporations have allowed their workers to work from home, and many businesses are creating flexible working programs in case they decide to adopt remote working arrangements [3]. While the ability to work from home is an advantage to many workers, other businesses lack the foundation of the technological infrastructure to give the capacity of "business as usual" without some compromises.

Yet one interesting finding of COVID-19 is that businesses understand the value of fast-tracking digital transformation. As many cities around the world were shut down as COVID-19 grew, the government and several businesses allowed millions to stay at home, encouraging them to experience the joys and chaos of working from home. While some businesses will inevitably return to strict work-in-office practices, others are required to understand the benefits of remote working. If for nothing else, they will have good knowledge of what is needed and how to meet potential work-from-home demands when it is needed again because of another disease or other factors. Theoretically, Papadopoulos et al. (2020) [4] have 
examined the use of digital technologies by small and medium enterprises during COVID-19. Pedersen and Ritter (2020) [5] also looked into preparing business for a post-pandemic world, while Ting et al. assessed the role of digital technology in COVID-19. However, the goal of this paper is to develop a conceptual framework on digital transformations antecedents of businesses post-pandemic outbreak.

\section{Conceptual Review}

\section{Concept of pandemic}

A pandemic is a new epidemic occurring across the globe. A pandemic happens as a new virus is arising and spreads across the world and many individuals are not resistant [6]. Viruses that triggered previous pandemics usually arose from influenza viruses in animals. Different forms of pandemics may appear similar to seasonal influenza while others may be very different. In all age ranges, pandemics will cause infections and most cases may result in selflimited illness in which the person recovers entirely without treatment [7]. Usually, however, pandemics cause most of the deaths in the aged while other serious cases occur more often in individuals with a number of health conditions. However, in pandemics, the effect or magnitude appears to be higher in part due to the much greater number of individuals in the world who lose pre-existing immunity to the new virus [8]. When a substantial majority of the population is infected, even though the percentage of those affected who tend to experience serious illness is small, the overall number of extreme cases is usually very high [9]. First and foremost, a pandemic epidemic is a human disaster which affects hundreds of thousands of people having an increasing impact on the global economy [10]. The next segment seeks to give an insight into the consequences for the workplace and organizations.

\section{The Effects of COVID-19 Pandemic on Businesses}

Undoubtedly, all business establishments, irrespective of their strength and type of industry, have been affected greatly by the coronavirus pandemic. With the entire sectors of economies coming close to a standstill (and the countries under lockdown) business operations have suffered terribly [11]. Probably the most daunting problem facing companies is the transitioning of employee operations onto online channels to enforce a work-from-home program and ensure consistency of workflow. Given the need for technical innovations and industry experience, an overwhelming majority of the population is still not properly prepared to take advantage of the various advantages provided by these programs, primarily due to lack of proper infrastructure and knowledge [12]. Consequent upon the burden from the pandemic crisis, business processes in most sectors are seriously disturbed Companies need to change rapidly to preserve stability and to de-risk their activities to support their customers today and in the future. Automating daily tasks with digital models, where everybody is a knowledge worker, would help benefit businesses and prepare them for production postCOVID-19 [13]. Now, more than ever, organizations need to concentrate on those business production and processes areas that can flourish in a post-pandemic environment.

Direct-to-consumer firms and business-tobusiness organizations struggle to meet humanitarian concerns as a matter of urgency. The coronavirus pandemic has ignited a new wave of trade disruption and new purchasing behaviors are likely to persist after the pandemic is over [14]. Those who treated digital business as a secondary medium now need to reprioritize their business with a digital focus. The COVID-19 pandemic is quickly accelerating the global international trade transition. The effect of the coronavirus epidemic forces businesses to change at an accelerated pace, which means reassessing how workers provide specific consumer services, where they operate, and how new platforms can be used to help the development of contact centres [15]. During this time, company owners who can transition to innovative ways of operating help mitigate future sales loss, create new rates of confidence in their employees and prepare their firms for sustained growth after the pandemic subsides.

Now supply chains are more important than ever before. Companies need to provide goods and services effectively, accurately, and safely, especially to those at risk of infection or who work at the frontline of medical response, such as life science companies developing COVID-19 tests and therapies [16]. In fulfilling this unparalleled demand, corporations have a duty to protect their employees' health and safety, their supply chain staff, and the local communities in which they reside, in ensuring the necessary flow of goods and resources. Companies need to establish a quick plan to tackle the existing challenges and improve processes to prepare for potential threats to the supply chain. Companies will need to work out how to use technology and automation to navigate the complexities of the supply chain, discover ways to minimize the uncertainty, and rapidly build a comprehensive strategy to distribute products and services despite the situation created by COVID-19 [17].

The COVID-19 outbreak's biggest immediate effect is on people. Organizations concentrate on providing for their employees while quickly handling 
the transition to new working patterns [18]. At this crucial moment, business leaders need to see these modifications in ways that achieve and sustain stakeholder's trust. It takes leadership teams who can adapt proactively anticipating the changing needs of stakeholders. COVID-19's key external impacts include the need to transition to remote jobs, along with organizational structures for increased sick leave [19]. Although COVID-19 is the catalyst for accelerated implementation of a digital revolution, there is a propensity that the crisis will fundamentally transform how employees work and communicate [16].

\section{The Concept of Digital Transformation}

Digital transition is a cultural, systemic, and operating change of an institution, sector, or ecosystem by the strategic application of new technology, systems, and competences at all levels and functions [20]. Digital transformation leverages value-creating technologies for different stakeholders, innovates, and builds capacity to adapt quickly to changing circumstances. Digital transformation is a method of leveraging emerging technology to build new business structures, culture, and consumer service or to change current ones to fulfill changing industry and market needs [21]. The digital revolution has had a major effect on companies; transforming company operations and processes to take full advantage of opportunities. This goes beyond conventional positions of advertising, promotion, and customer care. Rather, digital innovation continues and ends with the way companies and organizations think about consumers and involve them. Although digital transformation is mainly used in a business sense, it also involves other organizations such as governments, public sector institutions, and organizations engaged in solving social issues such as emissions and ageing by exploiting one or more of such current and evolving technologies [22].

\section{COVID-19 and Digital Business Transformation}

Digital transformation is now more than ever a critical issue for all companies, brands, and enterprises on the advent of COVID-19. Globally, only a few companies have been actively successful in digital transformation in decades [23]. In some cases, businesses that have not been successful with digital transformation are still in the course of recovery. Nonetheless, the world has been left with no alternative by coronavirus. Companies must transform digitally and fast, to ensure the safety of employees and move all operations remotely [24]. Companies that have been thought to be digitally transformed where employees could operate remotely have been put to the test. Situations for workers may have changed drastically from the norm ranging from children being home due to school holidays to a parent losing a job, to families who are personally affected by coronavirus themselves. It is therefore important for managers to understand the complexities of working remotely and to develop effective digital communication infrastructure, especially when all circumstances at this time may be uncertain [25]. As long as physical and social distancing remains critical, businesses need to be digitally versatile. Organizations need processes and tools that can collaborate and execute activities successfully with all workers. With digital change, businesses take a step back to review business operations, processes, and customer experiences [26]. Businesses will have to question the possibility of evolving procedures in a manner that allows faster decision-making, gamebreaking efficiencies, and more customized consumer service.

Now, in this digital age companies are finding innovative, efficient, and revolutionary ways to exploit technology [27]. A core part of the digital transformation is understanding the potential of technology [28]. Digital revolutions have already reshaped how companies handle customer service. The old model was waiting for consumers to come and contact you, in person or by calling a phone. However, social media's growth has transformed businesses through advertisements, marketing, and customer support and revenue models [29]. Progressive companies accept social media as an incentive to expand their service capabilities by reaching customers on their sites of convenience. While digital transformation has been on the radar of most companies for some time, the seriousness of COVID-19 is forcing forward-thinking companies to accept this pandemic wholeheartedly; hence, there is a need to examine the antecedents for digital transformation after this pandemic

\section{Digital Transformation Antecedents Post-pandemic}

\section{initiatives \\ Smart capital allocation for digital}

Allocation of capital involves managing and spending the financial resources of a business in ways that improve its productivity and boost its earnings [24]. Management of a company tries to distribute its resources in ways that would produce as much income for its owners as possible. Capital management is difficult, and the success or loss of a company often rests 
on the capital-allocation choices of a CEO. Management considers the feasibility of the available investment options, evaluate the possible impact of each on the company, and distribute the additional funds reasonably and in a manner that will yield the best overall returns for the business. Digital transformation means something different to every company. It is a broad concept that encompasses using technological advances to do business in new and more efficient, effective ways [30]. Investing smartly on digital transformation depends on a lot of things, including the size of your organization and its unique set of barriers and priorities [31]. As a rule of thumb, it is best for businesses to ensure that their IT environment and infrastructure runs smoothly and securely as important changes are made. It is imperative for businesses to eliminate current, nonstrategic IT spending waste, and redirect funds to digital transformation initiatives. This will facilitate smart capital allocation strategies that foster digital transformation while also enhancing productivity.

\section{Engagement of appropriate digital tools}

One of the implications for the workforce of the COVID-19 pandemic is that it is likely that at least some workers will operate remotely, even though the rest will return to the office to facilitate physical distancing enforcement. The question of how the remote working members of the work team will be supported comes to the fore. This emphasizes the role of engagements in tools or technologies in maintaining cohesion with remote work place teams and addressing the challenges for separated teams [32]. Digital technologies are electronic data producing, storage, or computing software, programs, computers, and services. Considering the possibility of collaborative work teams, there is a long-term need for an organizational policy rework [33]. This may include improved or more reliable network and server connectivity, ability to hold structured electronic business events, new handheld or portable computers, interactive networking and communication tools, and more [34]. For many workplaces that may have been risk averse, this will require taking smart risks to foster business continuity or survival of business and workplace operations [35].

\section{Talent recruitment}

Digital transformation post-COVID-19 will have implications for talent recruitment for the workplace [36]. Workplace leaders will need to make smart staffing decisions quickly. This may involve employment of new employees or talents that may not yet exist in a workplace but needs to be brought in as a team member in the workplace [30]. There may be a need to ascertain if the teams have the right kind of skills for these individuals [37]. It is necessary to ascertain whether these talents are collaborative and communicative in view of the fact that information technology cannot work in a silo, and

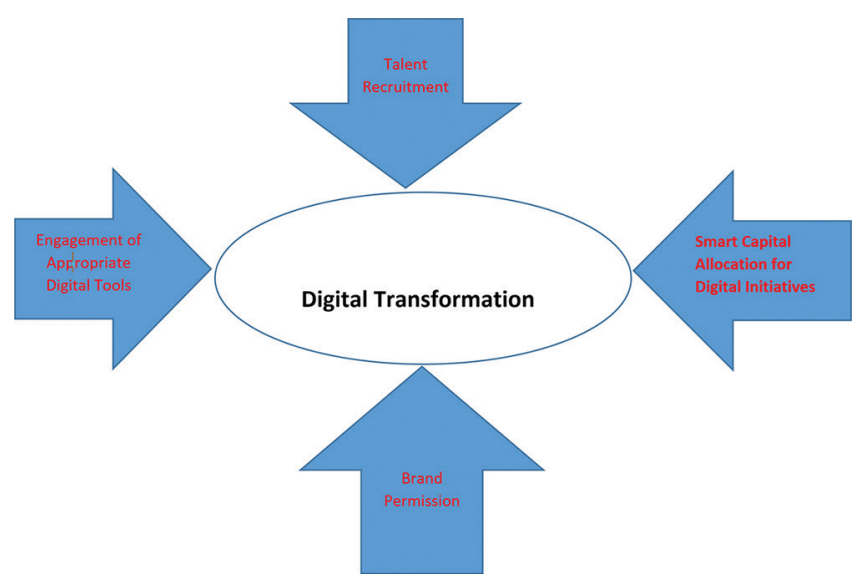

Figure 1: A conceptual framework on COVID-19 pandemic and antecedents for digital transformation in the workplace

that team members need to be able to communicate what they are doing and why, and be clear about how their action is aligned with broader objectives [31]. There could also be a need to crack down resource management restrictions to invest in young talents who not only have the right skills but also who can increasingly educate current teams about new resources [35].

\section{Brand Permission}

As workplaces around the globe work through accelerated digital transformation, many organizations will start to think about their business as a truly digital brand. There is a likelihood to begin consider an organization or a workplace as a digital brand especially when staff have begun to operate and work remotely. However, there is a need to clarify the concerns of brand permission for an organization [38]. Brand permission defines the limits of customers' willingness to accept a familiar brand name in new marketplace situations [39]. In this light, it might be challenging for an organization to communicate business operations to customers/new recruit as digitally transformed and expect the market to immediately accept especially when there had not been any history of digital operations [40]. Organizations will have to earn this right to operate digitally considering that brand permission is something a workplace team leader and the rest of team will need to work on by largely focusing on delivery of useful and impactful digital products and services to attract new talents, retain customers, and attract new ones [41] (Figure 1).

\section{Conclusion}

Digital transformation includes an intense change of corporate and operational practices, 
procedures and competencies, and templates to enhance the way business is managed. Digital strategy's aim is to improve customer engagement and maximize the strategic edge of the company, as well as market stability or longevity. Digital transformation is much harder to accomplish than conventional strategies. Nevertheless, the results from the most effective transformations point to four antecedents; Smart Capital Allocation for Digital Initiatives, engagement of appropriate digital tools, talent recruitment, and brand permission. The global pandemic has created a whole new experience for businesses and organizations around the world. Business executives cannot sit on their laurels any longer and definitely they cannot put off a digital transformation agenda. Therefore, taking the right decisions today would help ensure that businesses are better placed after the pandemic is over.

\section{References}

1. Baber WW, Ojala A, Martinez R. Transition to Digital Distribution Platforms and Business Model Evolution. United States: Proceedings of the $52^{\text {nd }}$ Hawaii International Conference on System Sciences; 2019. https://doi.org/10.24251/ hicss. 2019.600

2. Baiyere A. Discovering the Role of Information Technology In Disruptive Innovations-Enabler, Sustainer or Barrier. 2016:28-44.

3. Berghaus S, Back A. Stages in Digital Business Transformation: Results of an Empirical Maturity Study. Malaysia: MCIS; 2016. p. 22.

4. Papadopoulos T, Baltas KN, Balta ME. The use of digital technologies by small and medium enterprises during COVID-19: Implications for theory and practice. Int $\mathrm{J}$ Inf Manage. 2020;2020:102192. https://doi.org/10.1016/j. ijinfomgt.2020.102192

5. Pedersen CL, Ritter T. Preparing Your Business for a Postpandemic World. Massachusetts: Harvard Business Review; 2020.

6. AVAC: Global Advocacy for HIV Prevention. COVID-19 Resources for Advocates. Available from: https://www.avac.org/ covid-19-resources-advocates. [Last accessed on 2020 Oct 26].

7. CDC. Stress and Coping. Available from: https://www.cdc.gov/ coronavirus/2019-ncov/prepare/managingstress-anxiety.html. [Last accessed on 2020 May 01].

8. IAS. COVID-19 DSD Resources; 2020. Available from: http:// www.differentiatedcare.org/Resources/ResourceLibrary/ COVID-19-DSD-resources. [Last accessed on 2020 May 01].

9. ITPC. Personal and Community Guidance-coronavirus Disease (COVID-19); 2020. Available from: http://www.itpcglobal.org/ resource/personal-and-community-guidance-coronavirusdisease-covid-19. [Last accessed on 2020 May 01].

10. UNAIDS. What People Living with HIV Need to Know About HIV and COVID-19; 2020. Available from: https://www.unaids.org/en/ covid19https://saafrica.org/new/wp-content/uploads/2020/03/ hiv-andcovid19 infographic A3 en.pdf. [Last accessed on 2020 May 01].

11. Ozili PK, Arun T. Spillover of COVID-19: Impact on the Global Economy; 2020. Available from: https://www.ssrn.com/ abstract $=3562570$ [Last accessed on 2020 May 01].

12. GHS Index. Global Health Security Index 2019. Nuclear Threat
Initiative, Washington, DC: Johns Hopkins Center for Health Security, Maryland; and the Economist Intelligence Unit, London; 2020. Available from: https://www.ghsindex.org. [Last accessed on 2020 May 01].

13. Maeva C, Jamie R, Tom O. How Much Coronavirus Could Hurt GDP, a Look at the Scenarios, from Bad to Worse. New York, United States: Bloomberg Businessweek; 2020.

14. McKibbin WJ, Fernando R. The Global Macroeconomic Impacts of COVID-19: Seven Scenarios. Mumbai: CAMA Working Paper No. 19/2020; 2020

15. National Bureau of Statistics of China. Impact of Covid19 in the First Two Months. Beijing, China: National Bureau of Statistics of China; 2020.

16. UNECA. Economic Impact of the Covid19 on Africa, Economic Commission for Africa. Addis Ababa, Ethiopia: UNECA; 2020.

17. AFDB. African Economic Outlook. Abidjan, Cote d'Ivoire: AFDB 2020.

18. AUC/OECD. Africa's Development Dynamics 2019: Achieving Productive Transformation. Addis Ababa: OECD Publishing, Paris/AUC; 2019. Available from: https://www.au.int/en/ afdd2019.

19. Assessment Ol. Coronavirus: The World Economy at Risk. Organisation for Economic Co-operation and Development. France: Assessment Ol; 2020

20. Berman $S$, Marshall $A$. The next digital transformation: from an individual-centered to an everyone-to-everyone economy. Strategy Leadership. 2014;42(5):9-17. https://doi.org/10.1108/ sl-07-2014-0048

21. Bharadwaj A, El Sawy OA, Pavlou PA, Venkatraman N. Digital business strategy: Toward a next generation of insights. MIS Quart. 2013;37(2):471-82. https://doi.org/10.25300/ misq/2013/37:2.3

22. Boccardi F, Heath RW, Lozano A, Marzetta TL, Popovski P. Five disruptive technology directions for 5G. IEEE Commun Mag. 2014;52(2):74-80. https://doi.org/10.1109/mcom.2014.6736746

23. Bussgang JJ, Clemens S. Continuous Development Will Change Organizations as Much as Agile Did. United States: Harvard Business Review; 2018.

24. Chanias S. Mastering Digital Transformation: The Path of a Financial Services Provider Towards a Digital Transformation Strategy. Portugal: Proceedings of the $25^{\text {th }}$ European Conference on Information Systems (ECIS), Guimarães; 2017. p. 16-31.

25. Chanias S, Hess T. How digital are we? Maturity models for the assessment of a company's status in the digital transformation. Manage Rep. 2016;2:1-4.

26. Chanias S, Hess T. Understanding Digital Transformation Strategy formation: Insights from Europe's Automotive Industry. Kolkata: PACIS; 2016. p. 296.

27. Dery K, Sebastian IM, van der Meulen N. The digital workplace is key to digital innovation. MIS Quart Exec. 2017;16(2):135-52.

28. Deloitte Review. The Industry 4.0 Paradox. Overcoming Disconnects on the Path to Digital Transformation. London, United Kingdom: Deloitte Review; 2019.

29. Eden R, Jones AB, Casey V, Draheim M. Digital transformation requires workforce transformation. MIS Quart Exec. 2019;18(1):1-17. https://doi.org/10.17705/2msqe.00005

30. El Sawy OA, Kræmmergaard P, Amsinck H, Vinther AL. How LEGO built the foundations and enterprise capabilities for digital leadership. MIS Quart Exec. 2016;15(2):141-66. https://doi. org/10.4324/9780429286797-8

31. Gust G, Neumann D, Flath CM, Brandt T, Ströhle P. How a traditional company seeded new analytics capabilities. MIS Quart Exec. 2017;16:215-30.

32. Fichman RG, Dos Santos BL, Zheng Z. Digital innovation as a fundamental and powerful concept in the information 
systems curriculum. MIS Quart. 2014;38(2):329-53. https://doi. org $/ 10.25300 / \mathrm{misq} / 2014 / 38.2 .01$

33. Fitzgerald M, Kruschwitz N, Bonnet D, Welch M. Embracing digital technology: A new strategic imperative. MIT Sloan Manage Rev. 2014;55(2):1-12.

34. Gerster D. Digital Transformation and IT: Current State of Research. Kolkata: PACIS; 2017. p. 133.

35. Gimpel H, Hosseini S, Huber RX, Probst L, Röglinger M, Faisst U. Structuring digital transformation: A framework of action fields and its application at ZEISS. J Inf Technol Theory Appl 2018;19(1):31-54.

36. Grover $\mathrm{V}$, Kohli R, Ramanlal P. Being mindful in digital initiatives. MIS Quart Exec. 2018;17(3):223-36.
37. Kane GC, Palmer D, Phillips AN, Kiron D, Buckley N. Strategy, Not Technology, Drives Digital Transformation. London, United Kingdom: MIT Sloan Management Review and Deloitte University Press; 2015. p. 14.

38. Yovanno D. Why Permission Marketing Is the Future of Online Advertising. 2011.

39. Saarbeck S. Permission Marketing. Wiesbaden: Springer Gabler; 2014.

40. Master Base. Permission Marketing; 2014. Available from: http://www.Archivedcopy. [Last accessed on 2020 May 01].

41. Godin S. Permission Marketing: Turning Strangers into Friends and Friends into Customers. New York, United States: Simon and Schuster; 1999. 